JAN K. OSTROWSKI

\title{
A Great Baroque Master on the Outskirts of Latin Europe. Johann Georg Pinsel and the High Altar of the Church at Hodowica
}

After 250 years of its development history of art has in principle established a personal and territorial hierarchy of values. Today one can hardly count on any spectacular re-evaluations, and even less so on great discoveries, especially in the domain of European art. This situation results in equal measure from the development of art history itself as from the pressure exerted by the antiques, book, and tourist markets eagerly searching for new spheres of exploration and expansion. Under such circumstances the case of an artist of top class, but known solely to a narrow group of specialists, is something rare indeed. And such is the case of the oeuvre of Johann Georg Pinsel, a Late Baroque sculptor active in the eastern territory of the former Polish Kingdom (now Ukraine) in the third quarter of the $18^{\text {th }}$ century. The exceptional quality of his art and at the same time the astonishing paucity of biographical data, along with the dramatic fate of his works account for his being a fascinating figure not only because of the scale of his talent but also for the mystery that surrounds him. We know more about a good many medieval artists than about Pinsel. His name appeared in the literature as late as $1923^{1}$, but it was not until 1993 that his first and second names could be established as well as the approximate date of his death and a handful of details concerning his family life ${ }^{2}$. All the same, both the place and date of Pinsel's birth remain unknown, and so does the centre in which he received his artistic training. Despite this very scarce biographical information, the literature on Pinsel that has been increasing since the 1930 s is fairly abundant, and his oeuvre more or less accurately identified and correctly characterized ${ }^{3}$.

The fragment of Pinsel's biography and artistic activity that is known to us presents itself as follows. It is almost certain that the artist was ethnically German, though he could equally have come from the south of Germany (Swabia, Bavaria) as from Austria, Bohemia, Moravia, or Silesia. The date of his birth can be hypothetically established as about $1720^{4}$. His surname (transcribed in sources in different ways: Pinzel, Pinzenl, Pilse, Pilze, Pilznow, or Penzel) in the philologically correct version denotes "brush", this probably being a reflection of the painter's profession of his father or grandfather. In all likelihood he came to Poland around 1750 and settled at Buczacz (some $150 \mathrm{~km}$ to the south-east of Lvov, now Ukraine), where he set up a family ${ }^{5}$ and became court artist to Mikołaj Potocki, a rich and eccentric aristocrat and eminent art patron. The association with Potocki's household did not prevent Pinsel from accepting commissions from other clients. Most of his works were intended for the structures designed by the prominent architect Bernard Meretyn. The sculptor, together with his assistants, undoubtedly belonged to a stand- 
ing team of builders and decorators directed by Meretyn, the lump sum system used by that architect for settling accounts with the investors being one of the reasons for the paucity of data concerning Pinsel. This close collaboration came to an end only with Meretyn's death in 1759.

The sources contain information on Pinsel's work in no more than three places: the Trinitarian church (1756-1757, possibly one figure preserved) and the Greek-Catholic Cathedral of St George in Lvov (1759-1761, figures on the facade), and the church at Monasterzyska (1761, two extant figures). Furthermore, well-grounded attributions link with him the sculpted decoration of the Buczacz townhall (early 1750 s, badly damaged), complete interior decoration of the churches at Horodenka (c. 1752-1755, a few surviving, considerably damaged figures) and Hodowica (1757-1758, preserved almost complete, in the Lvov Art Gallery), and a few separate sculptures. Undoubtedly, Pinsel managed a workshop employing several assistants. From every indication Maciej Polejowski, the most remarkable exponent of the younger generation of artists of the Lvov school, was his pupil, while Antoni Sztyl (Still) was his collaborator, at least in the last stage the master's life.

Johann Georg Pinsel died towards the end of 1761 or early in 1762. The date of his death is delimited by the last recorded payments for his works at Monasterzyska in September $1761^{6}$ and the next marriage of his widow, Marianna, in October $1762^{7}$.

In view of no more than about ten years of Pinsel's activity in Poland it seems that the above-given list of his creations is complete or almost complete and that there is practically no more chance of its being essentially added to. Of course there remains a separate problem of Pinsel's work in the period preceding his settlement at Buczacz. Up to now we are completely in the dark about it; one of the obstacles to its possible identification in the future is the fact that in all likelihood Pinsel never attained the status of guild master ${ }^{8}$, which means that in the centres of the stabilized structure of municipal laws he could not undertake any independent task (while in the remote provinces of Poland the guild rights were treated liberally, and the constant shortage of qualified artists gave scope for commissions to those lacking formal qualifications).

The statement that in theory we know the relatively complete oeuvre of Pinsel from the period of his activity in Poland, is not, unfortunately, tantamount to the possibility of carrying out full-scale studies on it. Here we owe a more lengthy explanation of this state of affairs to the Western reader, who is not acquainted with the dramatic fate of the territories on which the artist worked. Pinsel's artistic legacy suffered some losses as early as the close of the $18^{\text {th }}$ century (secularization of the
Trinitarian church in Lvov, resulting in the destruction or dispersal of its furnishings) and in the $19^{\text {th }}$ century (a fire in the Buczacz townhall, which considerably damaged its sculpted decoration). A number of losses were also brought about by the First World War. However, when the 1920s and 1930s saw the commencement of intensive studies on $18^{\text {th }}$ century sculpture, there still existed the three largest sets of Pinsel's sculptures, which combined into the splendid decoration of church interiors at Horodenka, Hodowica, and Monasterzyska. Today the good quality photographs taken then are for us the invaluable documentation of objects now lost, as none of the abovementioned sets of sculptures has survived in its original spatial arrangement (the only extant intact work is the facade of the Cathedral of St George in Lvov, designed by Meretyn, with three monumental sculptures by Pinsel). It is especially distressing that the losses were not due to "objective" factors such as, for instance, hostilities or a fire, but were caused by deliberate human doing motivated by an insane ideology. When in 1939 the eastern territories of Poland were occupied by the USSR, this being ultimately sealed by the Yalta agreement, the Soviet authorities set about systematic disposing of any evidence of the previous political and cultural situation. An exceptionally intensive devastating fury affected the monuments of art of the Roman Catholic Church, this resulting from an enmity at many levels, as it were, towards religion as such, towards a religion particularly alien to Russia, and towards the Polish element on those territories, identified with Catholicism. It is only now that the actual extent of cultural losses caused between 1939 and 1989 can be gradually appraised, thanks to a systematic campaign of inventorying historical monuments ${ }^{9}$. As for sculptural complexes by Pinsel, almost totally destroyed are those which decorated the churches at Horodenka and Monasterzyska. On the other hand, practically all figures once forming part of the magnificent composition of the high altar in the parish church at Hodowica have been saved thanks to the efforts of the staff of the Lvov Art Gallery. Unfortunately, the church itself, an elegant structure designed by Meretyn, today presents a pitiful ruin beyond repair.

$$
\text { * } * *
$$

Nonetheless, the extant sculptured elements and the prewar documentation permit a fairly accurate reconstruction of the original condition of the Hodowica altar [Fig. 1] and an attempt at its analysis. The parish church in a village some 10 $\mathrm{km}$ to the south of Lvov, was built-on the site of an older one-between c. 1751 and 1758, thanks to the foundation of the Rev. Szczepan Mikulski, Archdeacon of Lvov. Bernard Meretyn's authorship, proposed as a well-grounded hypothe- 
sis by Tadeusz Mańkowski ${ }^{10}$, was borne out by the architect's signature discovered in 1965 on the back of a relief sculpture from the dismantled pulpit ${ }^{11}$. It was also Mańkowski who advanced the thesis of Pinsel as the author of the sculpted decoration of the church ${ }^{12}$; this, despite a polemic carried out for many years by Zbigniew Hornung (who attributed the sculptures to the Lvov artist Antoni Osiński) ${ }^{13}$, is no longer open to question. Mańkowski, considering the history of the church, held that the Hodowica sculptures could not have been executed later than $1758^{14}$, whereas Hornung dated them around $1762^{15}$. In this case, too, recent studies have confirmed Mańkowski's thesis (by 1762 Pinsel was dead, and in 1759-1761 he was engaged in Lvov and at Monasterzyska). Moreover, the discovery of an archival reference to the payment to the artist made by the Lvov Trinitaries in April $1757^{16}$ practically limits the acceptable dates of the creation of the Hodowica altar to two years -1757 and 1758 . This fact as well as a remarkable scale of the commission permit the assumption that it was carried out with participation of Pinsel's pupils and assistants. One of them was Maciej Polejowski, which can be gathered from his own letter of $1786^{17}$, and another-the master's anonymous collaborator, very close to him in respect of style ${ }^{18}$. The Hodowica altar was in fact a typical Late Baroque Gesamtkunstwerk, executed after Meretyn's design, by a team of artists specializing in wall painting and sculpture.

Despite its modest size the church at Hodowica was one of the most valuable examples of art of the third quarter of the $18^{\text {th }}$ century in the whole of Poland, on a par with the most outstanding monuments of this kind in Bavaria, Austria, or Bohemia. Its architectural solution derives from the type of church with a unified space, based on Italian models (Francesco Borromini, Guarino Guarini, the classical-eclectic circle of Carlo Fontana, and the Accademia di San Luca), in the territories of the Habsburg monarchy applied to modest village churches (Landkirchen), hospital churches, and cemetery chapels. Forms very close to those used at Hodowica appear in Austrian and Bohemian architects, such as, for instance, Johann Georg Aichbauer, Kilian Ignaz Dientzenhofer, or Franz Anton Pilgram. The work of the last of them-the hospital church of the Crusaders with the Red Star in Bratislava (1743-1745) - constitutes the closest known analogy to the ground plan of the Hodowica edifice ${ }^{19}$. The church at Hodowica is a cross-shaped structure with a short nave and a straight-ended chancel, and with a shallow transept situated half-way down the building. A square porch adjoins the facade, and a vestry is placed axially, behind the altar wall, thereby the plan of the structure being almost symmetrical to its transverse axis. Particular units of the interior are separated in a coulisse-like manner by prominent piers faced with
Corinthian pilasters. Corresponding with these distinct spatial divisions are the vaults designed independently for each unit of the structure and separated from one another by strongly articulated archivolts. The rather simple construction of the church was carried out meticulously by Meretyn's building team, and was decorated with high-quality stonework designed individually by the architect, above all with openwork vase-lanterns in the type of Rococo capricci ${ }^{20}$. The entire interior was covered with frescoes by Aleksander Roliński ${ }^{21}$. This painter was undoubtedly the weakest link in the whole team working at Hodowica. In fact, his role was limited to that of a mere executor. The architect and the author of the iconographic programme of the interior (the latter undoubtedly identical with the founder, Rev. Szczepan Mikulski) provided him with definite models to imitate, among which pattern designs by Andrea Pozzo and Giuseppe Galli Bibiena have been identified.

The authors of the Hodowica church focused their attention primarily on its two elements - the facade and the high altar, on which also the sculptures of immediate interest here were amassed. The facade is an elegant and elaborate version of the single-storied elevation with pilaster divisions, surmounted by a prominent gable. The linear treatment of wall surfaces and the fretted contour of the top were meant above all to produce the effect of a bright silhouette clear cut against the green of the hilly landscape. The sculptured decoration of the facade consists mainly of pilaster capitals, motifs adorning the volutes and pedestals of the gable, and the aforesaid vaselanterns. All these elements reveal a predominance of the rocaille ornament, in Poland in use from about 1750. The decorative motifs are distinguished by their originality and a wealth of concepts along with a very high quality of workmanship. Therefore, there can be no doubt about their designs being - at least in general outline-Meretyn's work, precisely fitted in with the overall architecture of the church, and about their execution under the direct supervision of Johann Georg Pinsel.

The high altar [Figs. 1, 2] presents much more complex artistic and iconographic problems. Its solution is most unusual. Meretyn gave up a traditional architectural retable in favour of a fresco covering the wall closing the chancel, which served as a background for sculptures in the round. This was a complete, conscious concept ${ }^{22}$, the form of the altar having been resolved as early as the stage of designing the architecture of the church. It was the decision to choose Giuseppe Galli Bibiena's design [Fig. 3$]^{23}$ as a model for the painted retable that determined the specific shaping of the wall. In the centre of it, a spacious arched niche was built in a special superstructure over the vestry. The aperture in the vault of the niche 


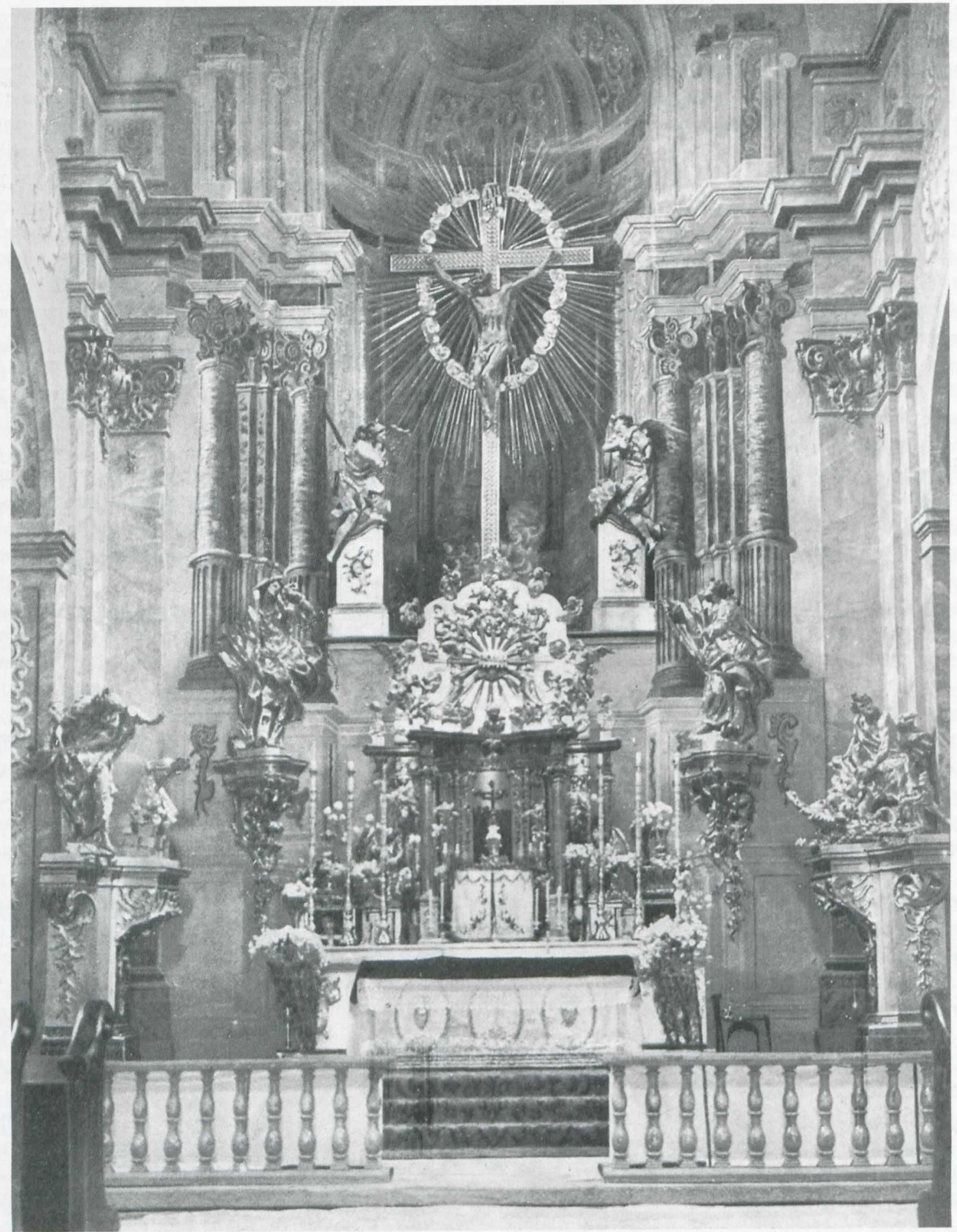

1) Hodowica, parish church. High altar, state c. 1935. After Mańkowski. 


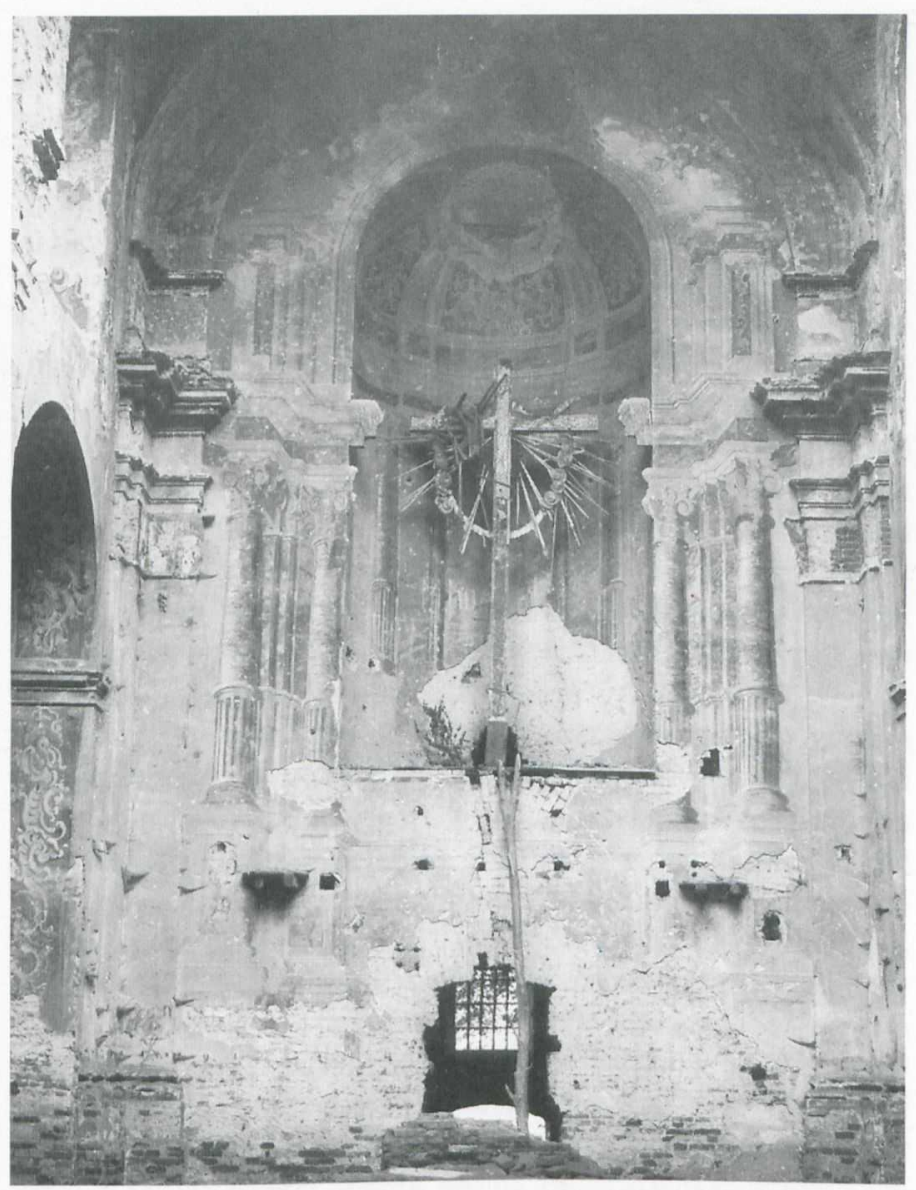

2) Hodowica, parish church. High altar, state 1990. Photo: J. K. Ostrowski.

communicates with a camera di luce, pierced with as many as four windows, in the upper part of the superstructure. In this way, the sculpture of the Crucified Christ, set up in the niche, was illuminated from the source of light concealed from the viewer, the light being distributed along the rays of the glory surrounding the cross. The sumptuous architectural framing of the niche was harmonized with real elements of the articulation of the church interior. This painted architecture formed a setting for three pairs of sculptures combining into a monumental pyramid with the figure of Christ at the apex, at the same time gradually protruding into the space of the chancel. Set directly below the cross were the figures of adoring

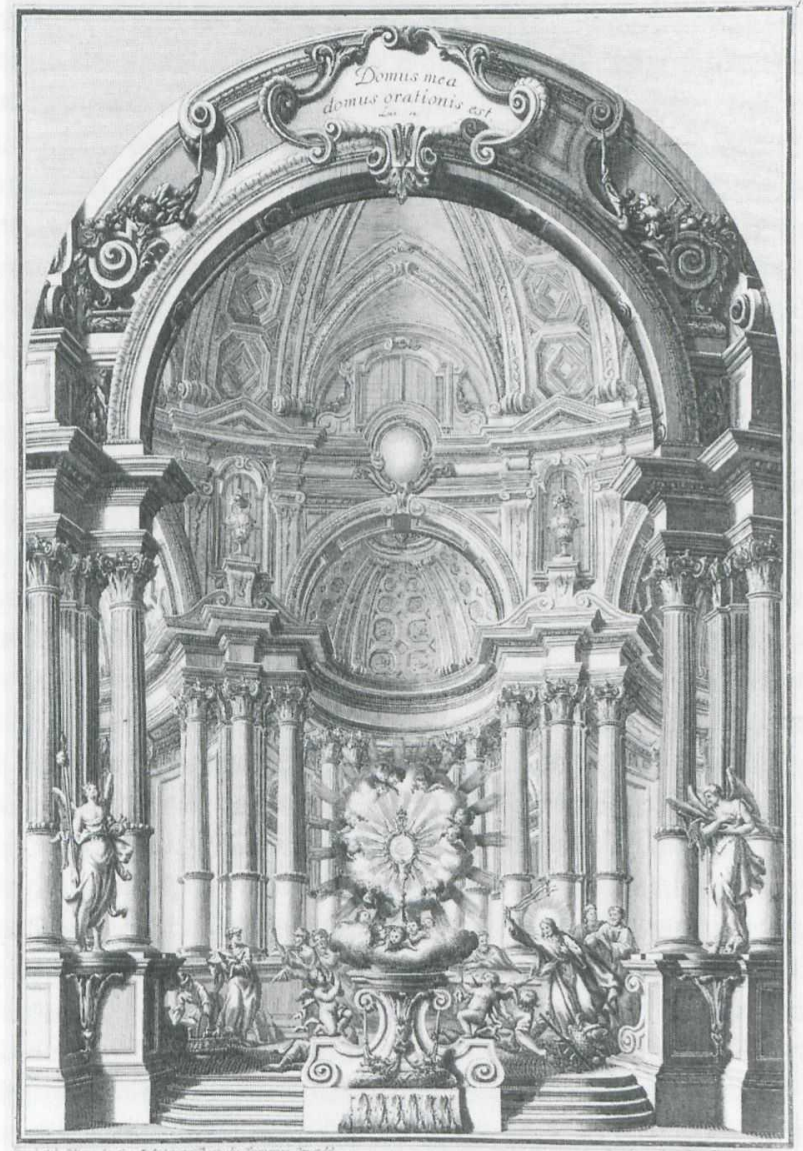

3) G. Galli Bibiena, design of a church decoration, 1740. Photo: S. Michta.

angels, kneeling on tall pedestals flanking the niche. The intermediate zone was formed by the statues of the Mother of Sorrows and St John the Evangelist, standing on splendid Rococo brackets attached to the altar wall. The third, lowest pair, most thrust forward into the church space, was formed by the groups of The Sacrifice of Isaac and Samson and the Lion. The centre was occupied by a free-standing mensa (its location, apart from the reasons of composition, resulted from the necessity of giving access to the vestry behind the altar), carrying an elaborate tabernacle with the throne for the Eucharist surmounted by a relief sculpture of the Apocalyptic Lamb in a glory. 
Painted retables occur very often in the art of the High and Late Baroque. However, after a strenuous search the monographer of Meretyn succeeded in finding only a single example of the combination of a painted altar structure with sculptures in the round (the Jesuit church at Oparaany, Bohemia, Kilian Ignaz Dientzenhofer, $1732-1735)^{24}$, which, as a matter of fact, cannot be treated as a prototype or even as a close analogy to the Hodowica solution. Even if we managed to point to other similar examples, the rarity and originality of Meretyn's concept is self-evident. One might of course ask whether this solution was a full success in its artistic aspect. Regrettably, the present condition of the building does not permit a full reception of its artistic message. One can only imagine that the plasticity and dynamic character of Pinsel's sculptures, set against Roliński's fresco of a rather indifferent quality, must have deepened the impression of the flatness of the painted architecture. It can hardly be assumed that Meretyn did not foresee such an effect. He evidently moved about with facility within the forms created by the idiom of the Late Baroque. He was familiar with Bernini's methods of enhancing the effects of illusion and expression (concealed source of light), but, in Piotr Krasny's opinion, by setting most of his figures in front of the niche, he relinquished the teatro nel teatro principle ${ }^{25}$. With regard to this last question a different hypothesis might be advanced, though in view of the present state of the church it would unfortunately be hard to verify. It cannot be excluded that the actual architectural frame for the Hodowica sculpted theatre was provided by the chancel arch resting on pillars in a coulisse-like arrangement and that the entire chancel space was its stage. The flatness of the fresco background could then have been not only accepted by Meretyn but even intended as a reference to real painted stage decorations.

The iconographic programme of the altar emphasizes the relationship between the Passion and the Eucharist. The Crucifixion scene, with the figure of Christ surrounded by the rays of a glory and with adoring angels, has been likened to the Host in a Baroque monstrance. Such a monstrance, in fact, appears exactly in the same place in Bibiena's engraving, which was used as a model for the Hodowica altar, and which is in fact a design of a setting for Forty Hours' Devotion. References to the Passion can be found in the scenes of The Sacrifice of Isaac (voluntary sacrifice) and Samson and the Lion (triumph of good over evil), forming part of the altar composition. As mentioned above, the idea of the programme, rather simple but excellently adapted to pastoral needs, should be associated with the founder of the church, the Rev. Szczepan Mikulski, a doctor of theology. The lucid presentation of the basic tenets of the faith was characteristic of the Catholic version of the Enlightenment ${ }^{26}$. Though we do not know much about the Rev. Mikulski's views, the problems of the revival of religious life based on rational foundations was not alien to the clergy in the apparently provincial territories of eastern Poland. An excellent example of an enlightened pastor and administrator was Waclaw Hieronim Sierakowski, who at the time of the building of the church at Hodowica was in charge of the neighbouring diocese in Przemyśl, and in 1760 was appointed archbishop of Lvov ${ }^{27}$.

The Hodowica altar, created by a group of artists of various specialties, in its overall design is undoubtedly the work of Bernard Meretyn. In accordance with the general practice of the Baroque period, an architect also exerted an important influence on the form of the figural sculptures incorporated into the composition. One can imagine that the design of the altar, unfortunately not preserved, included the disposition of miniature silhouettes of figures, drawn with painstaking preci$\operatorname{sion}^{28}$. Furthermore, Meretyn unquestionably took part in determining the details of the sculptured forms, for instance, by the choice of graphic models, and accepted their final execution. The last-mentioned practice is remarkably attested by his signature and seal on the back of a bas-relief from the drum of the pulpit ${ }^{29}$. Attempts at establishing more precisely Meretyn's contribution to the creation of the sculptures decorating his structures do not find any support in source material. Besides, they would be of little use in view of the architect's close professional and personal relations with Johann Georg Pinsel $^{30}$. Meretyn evidently considered the style of Pinsel's sculptures as complementary to his own architecture, and in the course of many years of the artists' collaboration its lasting, harmonious forms must have developed.

Apart from the above-presented role of the architect, the Hodowica figures bear an exceptionally strong stamp of Pinsel's individual style, ranking among the most valuable and most characteristic works in his oeuvre (it must be emphasized again that this is the only set of the artist's works in wood to survive as a whole). Therefore, a closer analysis of the technological and formal-stylistic aspects of the sculptures and of the problem of their impact on the art of the Lvov circle is an important element in attempts at the reconstruction of the personality of this eminent artist.

The figures of the altar at Hodowica were carved of limewood. The exposed parts of the body were covered with naturalistic polychromy and the remaining elements, above all the voluminous draperies, gilded. Thus Pinsel applied the technology going back to the Middle Ages and kept alive uninterruptedly in the tradition of the workshops of Central European woodcarvers. Pinsel's technical and artistic mastery in working wood is best revealed in the sculptures which have lost their polychromies and gilding, masking traces of technologi- 
cal measures (damaged figures from the churches at Horodenka and Monasterzyska). In at least two cases the artist made use of a specific technical device consisting in the addition of draperies to the already finished figures of Samson and Isaac in order to cover their nakedness (in all likelihood for the sake of decorum in a church), which were made of thick fabric stiffened with plaster-and-glue ground and finally gilded ${ }^{31}$.

All the figures are distinguished by the dynamism of composition and an extraordinary expression, aimed at revealing deep religious experience, combined with naturalistic detail. In shaping a three-dimensional figure an essential role is played by extremely sumptuous, swirling, as if metallic, draperies. Pinsel shares this last feature with the entire $18^{\text {th }}$ century Lvov school of sculpture. Nevertheless, unlike its other exponents (including his own collaborators and pupils), he never adopted the characteristic manner of geometrical stylization of folds with sharp, crisp edges.

Not only Pinsel's technology but also the main means employed by him to construct a form are rooted in Central European tradition, though the artist was not unfamiliar with post-mediaeval Italian models. The most individual feature of his art was the superb rendering of details of anatomy in singular, as though ascetic, stylization (hands and feet with long, distorted fingers and toes; oval faces with characteristic vertical furrows between the eyebrows; drilled locks of hair), while the structure of the figures, especially the musculature of nudes, was less convincing. Also a closer analysis of the physiognomies of Pinsel's statues leads to the conclusion that he did not have any deeper ability of rendering various psychological states, for the most part playing on a somewhat monotonous chord of pathos. These stronger and weaker aspects of Pinsel's art were evidently due to the character of his education. He must have taken a traditional course of guild training, sufficient for a talented adept to attain technical mastery, but giving him no chance to become acquainted with the canon of Renaissance and Baroque art, such as the classical principles of constructing a human figure (based on a study of the Antique and anatomy), with the methods of presenting the affetti, and with the construction of linear perspective ${ }^{32}$. Skills of this kind could be acquired mainly through academic studies, which surely neither Pinsel nor most of contemporary Central European woodcarvers ever completed. The aboveindicated gaps in Pinsel's education were made up for by his extraordinary talent and artistic conscientiousness, manifested in individual treatment of each, seemingly repeatable task.

Two of Pinsel's Hodowica sculptures have already been discussed in extensive monographs ${ }^{33}$, and the remaining ones also deserve closer analysis. The figure of the Crucified Christ [Fig. 4], an iconographic and compositional keystone of the altar, is one of a few versions of the subject in the artist's oeuvre. At the same time it should be emphasized that Pinsel handled each task individually, without copying earlier solutions. In the group of at least four Crucifixes by Pinsel the Hodowica sculpture stands at the "classicizing" extreme, near an example earlier by some years but unfortunately not preserved, which was once set up in the side altar of the church at Horodenka. In order to realize what the ideas of classicism and expression mean with regard to Pinsel's art, it is worth comparing the Hodowica Crucified Christ with an analogous work by Ignaz Günther in the church at Altmannstein (1764) [Fig. 6] ${ }^{34}$. Non-classical in itself, exhibiting Rococo fragility and grace, on comparison with Pinsel's work the sculpture of the Bavarian artist acquires classical features. However, for Pinsel the degree of anti-classical expression achieved in the discussed sculpture was only the first step in this direction. The full range of his abilities in this respect is illustrated by the Crucified Christ from the Church of St Martin in Lvov (now in the National Museum, Lvov) and a portable Crucifix [Fig. 5] from the church at Hodowica, which after the Second World War, together with the deported parishioners, found its way to Wroclaw. In the first of the sculptures the artist well-nigh reached the limit of his ability to drastically present the Agony on the Cross, verging on ugliness appalling in its naturalistic expressionism. The only adequate context for it seems to be found among $14^{\text {th }}$ century mystical Crucifixes. The small sculpture from Hodowica is even more extraordinary. Here Pinsel partly relinquished drastic accents, instead constructing the entire figure of flame-like sinuous forms, betraying an obvious kinship with the rocaille ornament ${ }^{35}$. His expressionism practically borders on abstraction, similarly as it happened a hundred and fifty years earlier in the works of El Greco and Milanese Mannerists. A further development in this direction was no longer possible without abandoning the illustrative role of art, which was not attempted before Vassili Kandinsky.

The very characteristic though no doubt mannered mode of constructing the naked body of the Crucified Christ, proposed by Pinsel, was widely accepted as a model by the Lvov school of sculpture, the Crucifix in the Hodowica altar playing here an exceptionally important role. One can enumerate some ten sculptures of the 1760 s and 1770 s, revealing compositional arrangements and, above all, the shaping of musculature that go back to Pinsel.

The figures of the angels adoring the Cross [Figs. 7, 8] originate - through a chain of repetitions in engravings and drawings - in the models of Gianlorenzo Bernini, popularized all over Central Europe ${ }^{36}$. Their scheme of composition was undoubtedly determined by Meretyn and Pinsel, but their exe- 


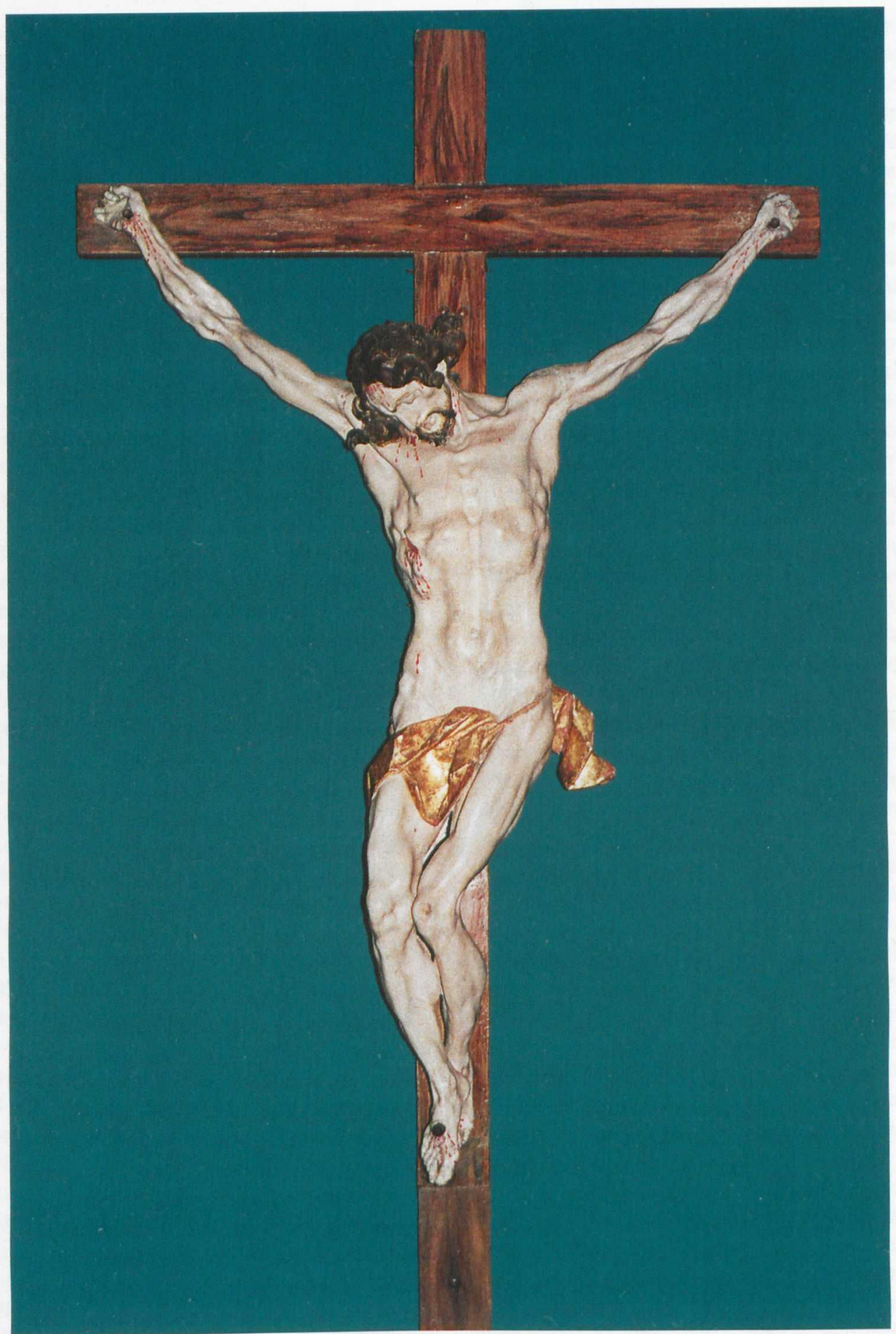

4) J. G. Pinsel, «Christ on the Cross», c. 1758, from the high altar at Hodowica. Lvov, Gallery of Art. Photo: J. K. Ostrowski. 


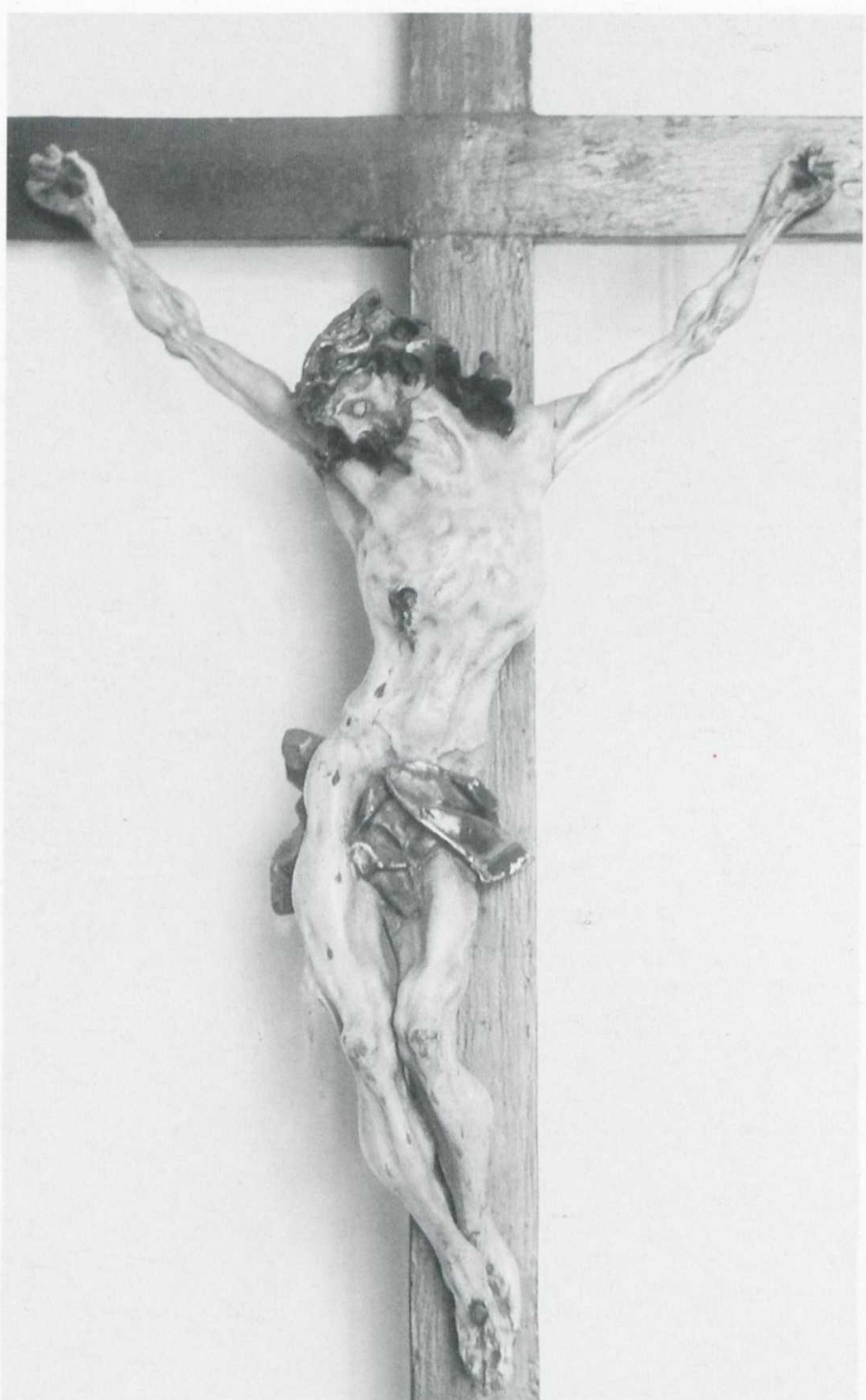

5) J. G. Pinsel, «Christ on the Cross», c. 1758, from the church at Hodowica. Wrocław, Holy Spirit Church. Photo: S. Michta.

cution was evidently entrusted to an anonymous member of the workshop, known from several works, mainly in Buczacz ${ }^{37}$. He did his utmost to imitate his master's style (whereby the somewhat inferior quality of the figures does not disrupt the stylistic unity of the altar); nevertheless, he was

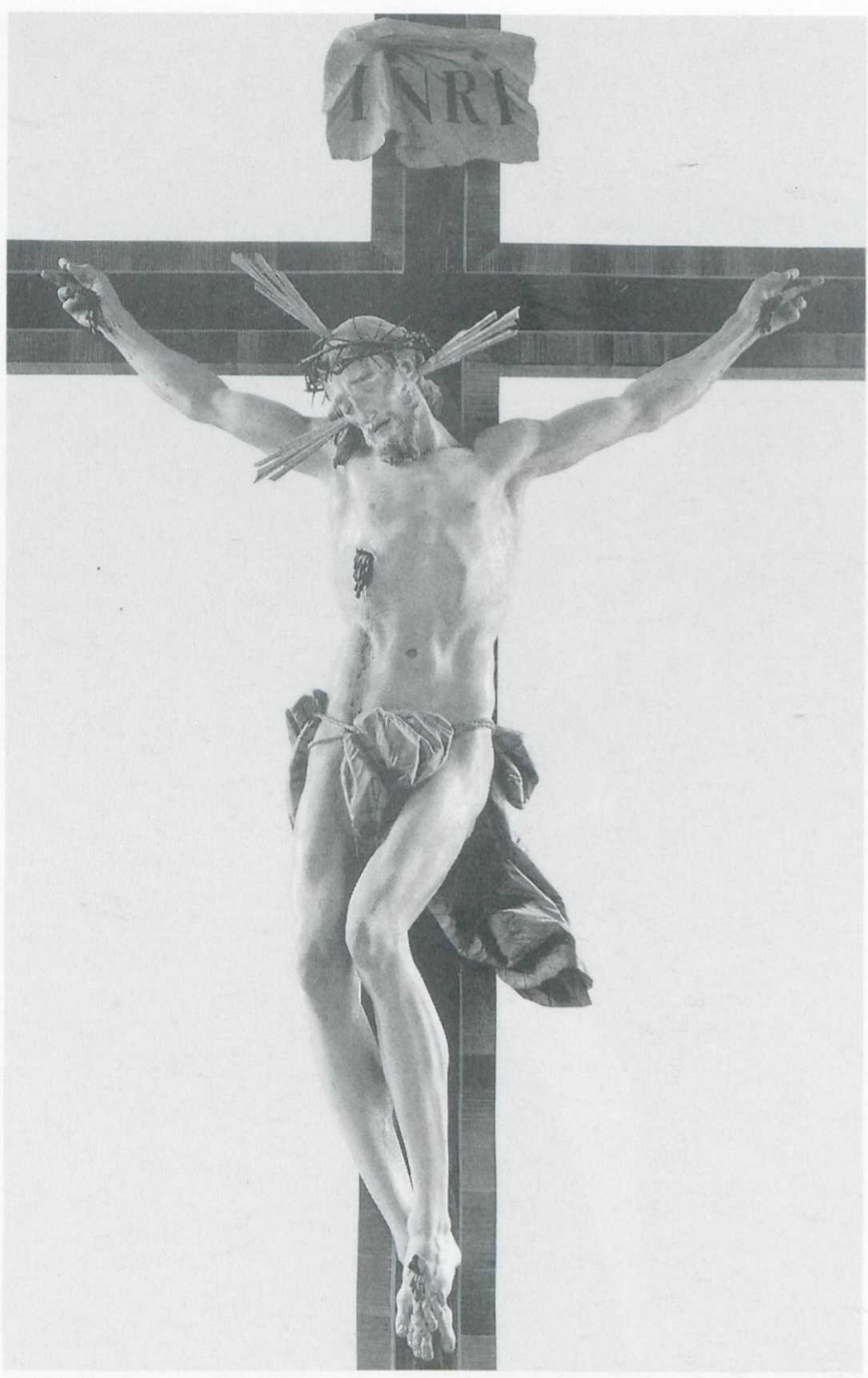

6) I. Günther, "Christ on the Cross», 1764, Altmannstein, parish church. Photo: W.-C. von der Mülbe.

unable to achieve the technical and expressive quality akin to Pinsel's. It is worth adding here that this artist, working in the immediate entourage of Pinsel, followed the manner of shaping metallic-crisp draperies, unlike Pinsel but typical of the remaining exponents of the Lvov school. Despite the above- 


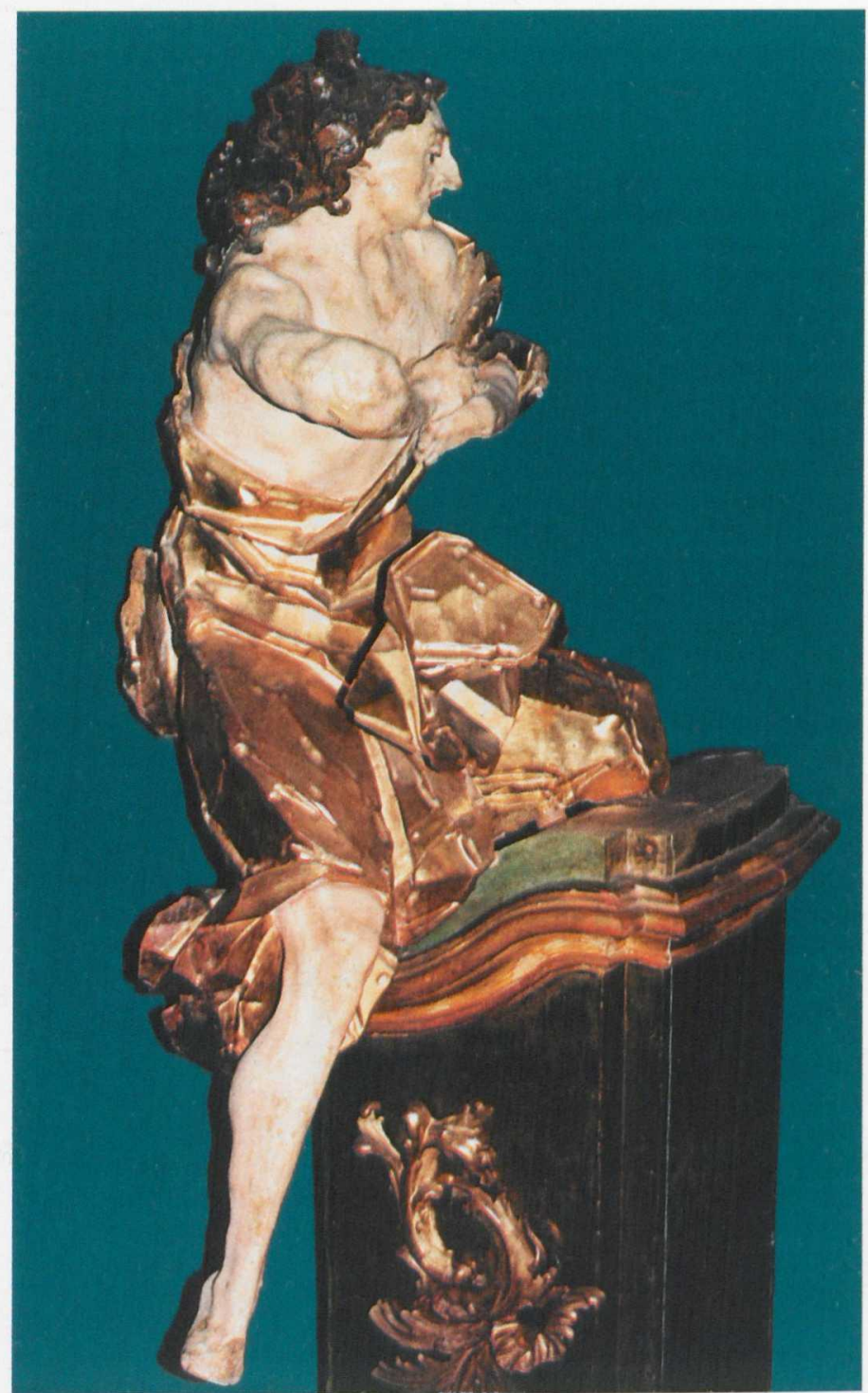

7) J. G. Pinsel's workshop, “Angel», c. 1758, from the high altar at Hodowica. Lvov, Gallery of Art.

Photo: J. K. Ostrowski.

mentioned relatively lower quality of the Hodowica angels, they have been repeated faithfully in the high altar of the church at Nawaria, in the neighbourhood of Hodowica ${ }^{38}$. These free copies were probably executed by Maciej Polejow-

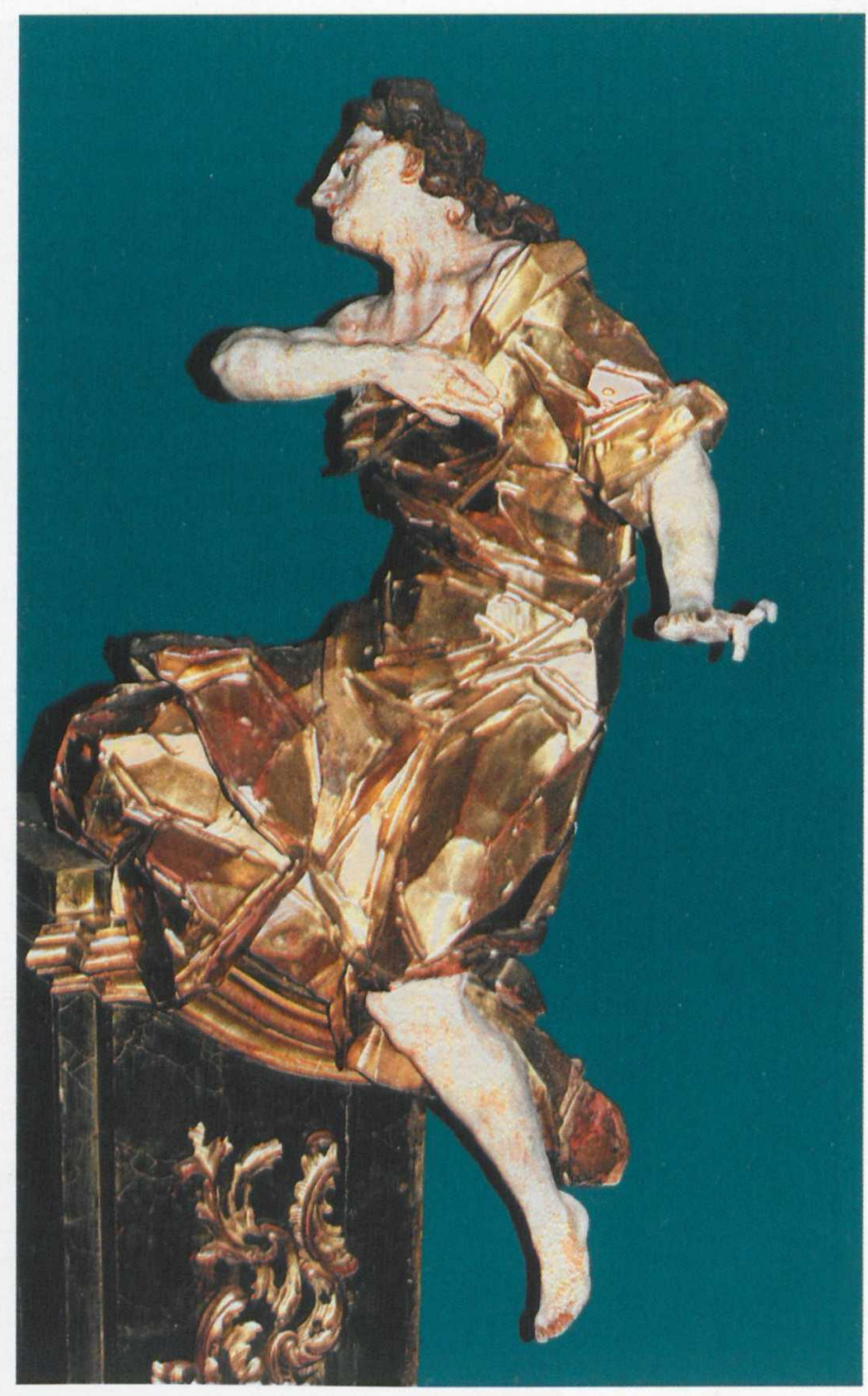

8) J. G. Pinsel's workshop, «Angel», c. 1758, from the high altar at Hodowica. Lvov, Gallery of Art.

Photo: J. K. Ostrowski.

ski, who in fact, as a pupil of Pinsel had participated in the decoration of the Hodowica church.

The Mother of Sorrows [Fig. 9], a left-side element of the second pair of figures, is one of Pinsel's most remarkable 


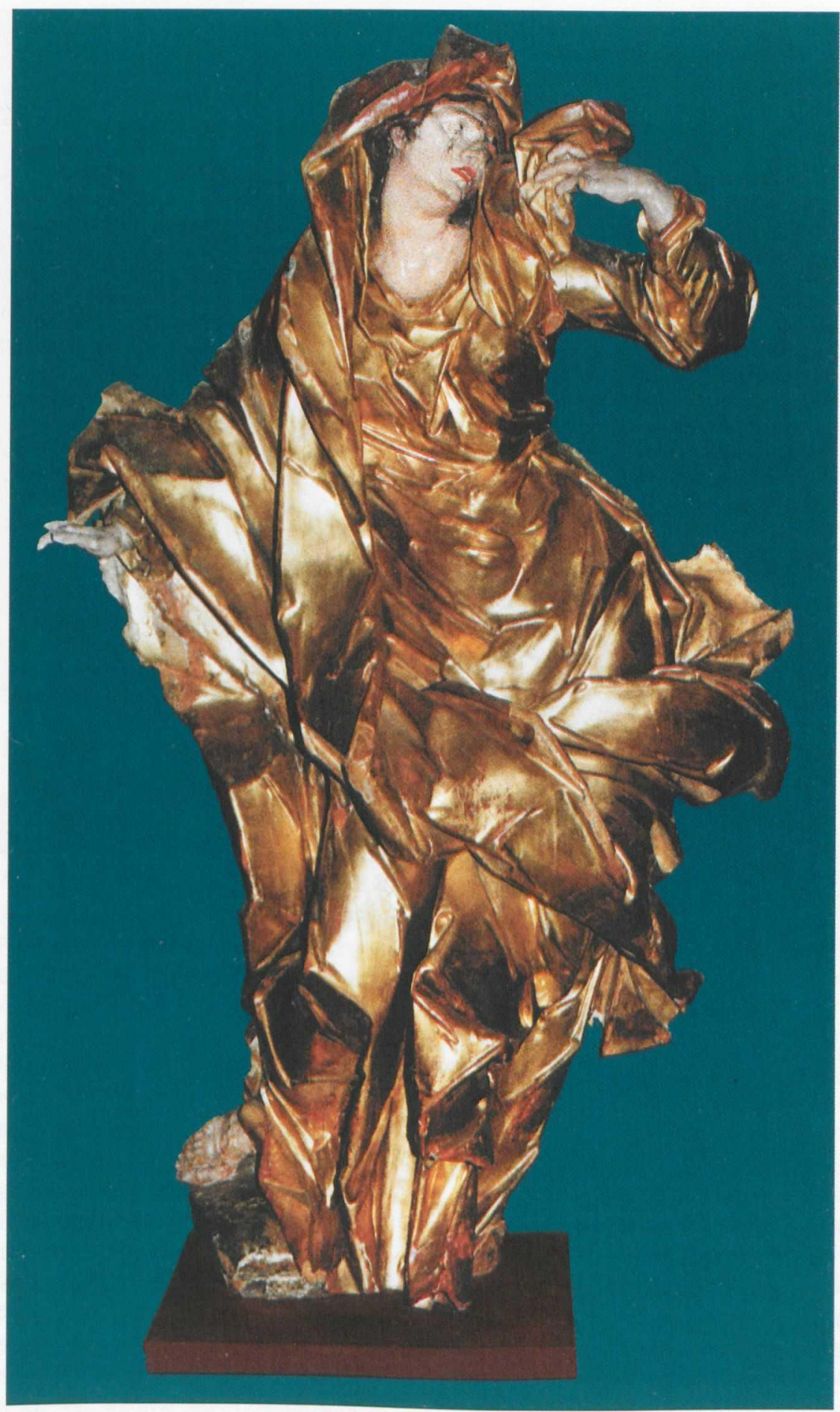

9) J. G. Pinsel, «Mother of Sorrows», c. 1758, from the high altar at Hodowica. Lvov, Gallery of Art. Photo: J. K. Ostrowski. 


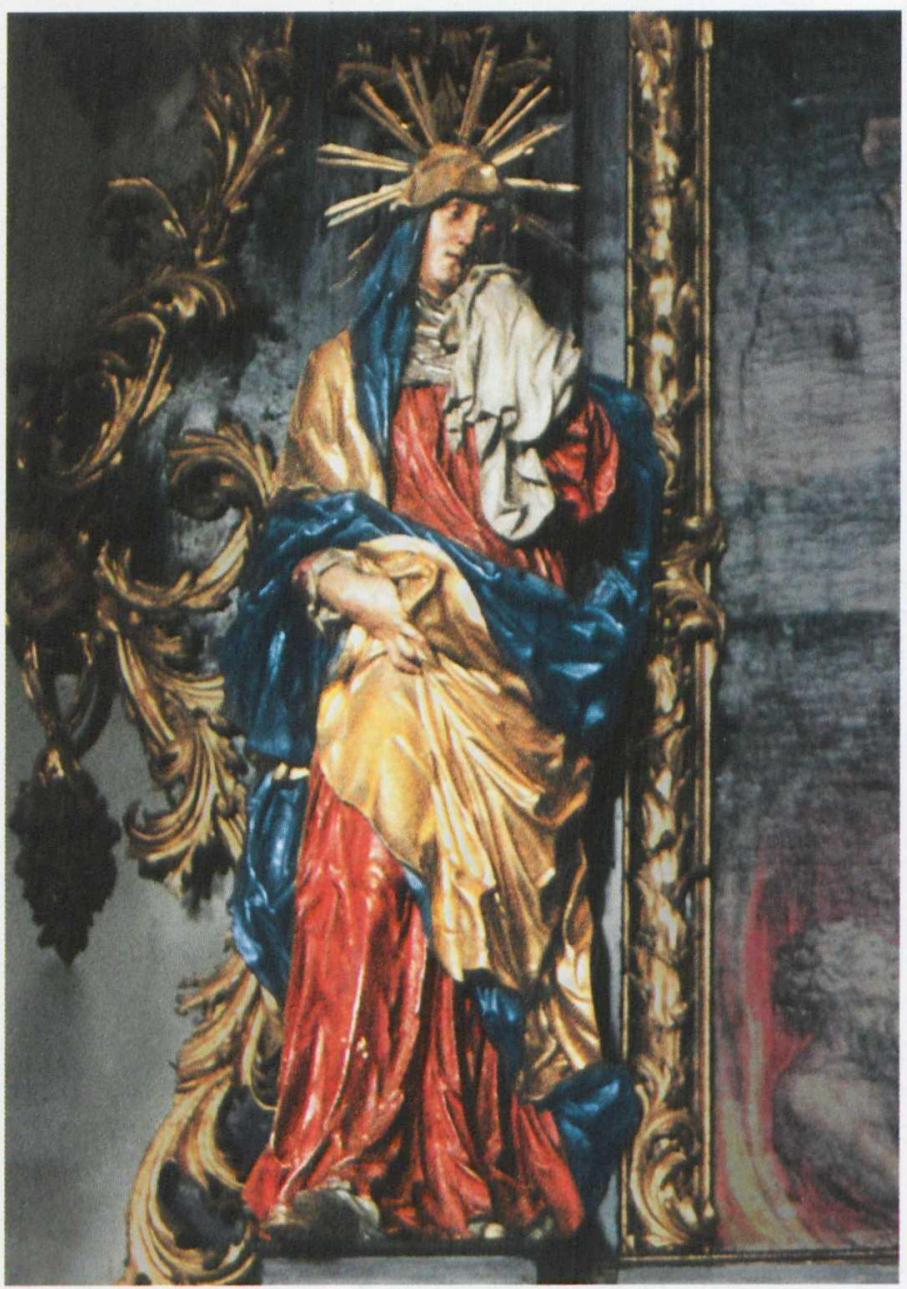

10) M. Guggenbichler, «Mother of Sorrows", 1704,

St. Wolfgang, parish church. Photo J. K. Ostrowski.

achievements. Rendered in a dancing contrapposto, enwrapped in extremely voluminous draperies, the figure - similarly as the aforesaid small Crucifix - verges on an ornamental-abstract composition. The Madonna is wiping the relief tears, running down the cheeks of her pain-stricken face, with a kerchief held in the left hand.

The sculpture of The Mother of Sorrows is strikingly beautiful. One admires the liveliness of her pose, precision in rendering anatomical details, and sumptuousness of the draperies. It is only on closer analysis that some doubts may arise

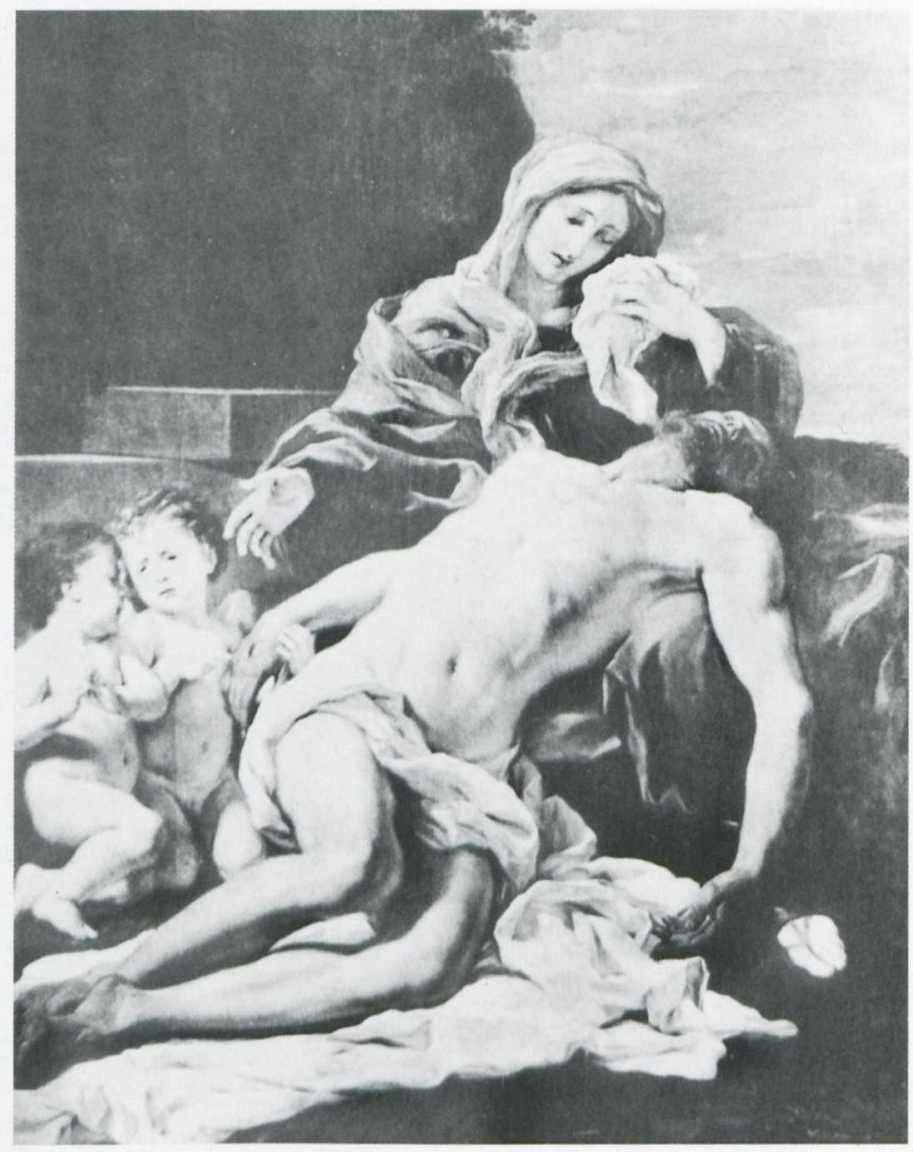

11) G. B. Gaulli called Baciccio, «Pietà», 1667. Rome, coll. Incisa della Rocchetta. After Enggass.

because of the conceptual discrepancy between the impression of that grandeur and beauty and the role played by the Mother of God in the drama of the Passion. In this respect Pinsel failed to achieve a complete unity of expression, though the characteristic motif of wiping tears with a kerchief may be accepted as his attempt to render human feelings in a natural way (imprese), this method deriving from the circle of Bernini ${ }^{39}$.

The very characteristic composition of the figure of The Mother of Sorrows, whose several variants occur in dozens of examples throughout Central Europe, induces us to search for its compositional prototype. In his recent study Piotr Krasny has only partially solved the problem. He pointed to the sig- 


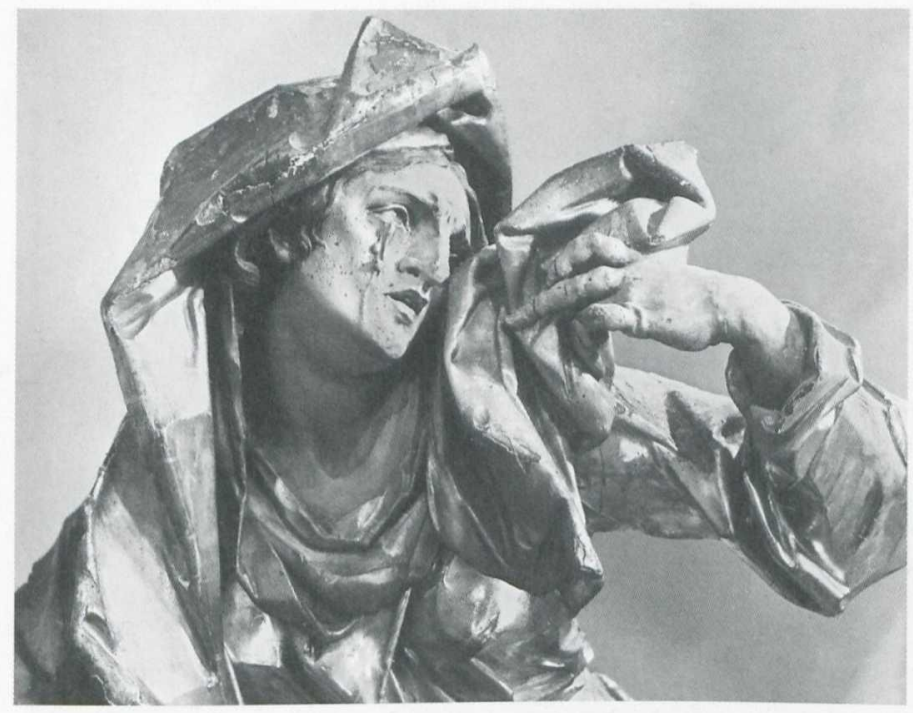

12) J. G. Pinsel, «Mother of Sorrows» (detail), c. 1758, from the high altar at Hodowica. Lvov, Gallery of Art.

nificance of the sculpture of The Virgin Mary, once an element of the Christ Parting from His Mother group which belonged to a Calvary (not preserved) in Bratislava. The figure itself, which in spite of damage (the left hand missing) has survived in the Museum of the City of Bratislava, is dated as 1694 and convincingly attributed to Giovanni Giuliani ${ }^{40}$. The original appearance of the group has come down to us thanks to an engraving by Johann Melchior Guttwein, published in a devotional book of 1723 on the Bratislava Calvary, whereby Giuliani's composition could be widely circulated. Of course, the sculpture of Giuliani, one of the prominent representatives of the Viennese circle in the early $18^{\text {th }}$ century, master of Georg Raphael Donner, may have exerted an influence even without any graphic intermediary. Piotr Krasny indicated a considerable number of examples, probably derived from the Bratislava statue, which have been preserved in Austria, Slovakia, Hungary, and even Poland ${ }^{41}$. Therefore, the importance of Giuliani's composition cannot be denied, though it does not seem to have been the direct prototype of Pinsel's sculpture. The Virgin Mary of Bratislava is rendered in a soft, gentle, classicizing and lyrical convention which has nothing in common with the dynamism derived from the Berninesque tradition, so excellently represented by Pinsel. Naturally Pinsel could refer to the Giuliani sculpture exclusively at the stage of

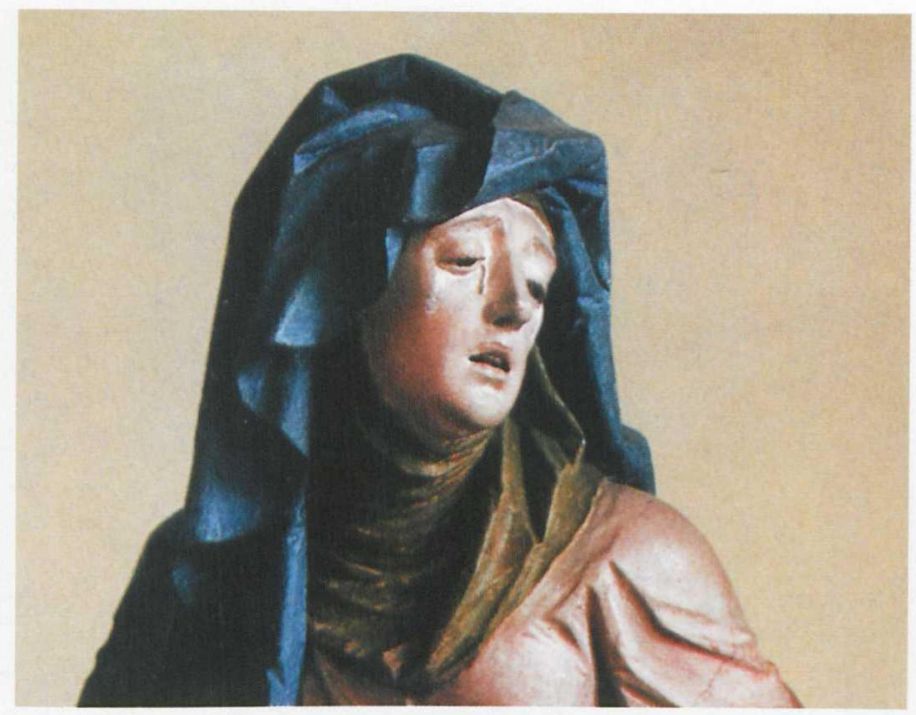

13) I. Günther, «Pietà» (detail), 1774, Nenningen, cemetery chapell. Photo: W.-C. von der Mülbe (reversed print).

an iconographic solution. It would not in fact be surprising if during his journeyman travels he stopped at Bratislava, which lay on one of some possible routes from Vienna to Poland.

However, he had at his disposal quite numerous similar models in European art, which were stylistically much closer to him. Especially two of them are worth noting, though they do not fully solve the question of the origins of the Pinsel figure either. The first is the painting of Pietà by Giovanni Battista Gaulli, called Baciccio, of 1667 (Rome, Incisa della Rocchetta collection) [Figs. 11, 12] ${ }^{42}$. In it the upper part of the figure of the Virgin Mary is in almost all details identical with Pinsel's sculpture, also the kind of expression and the mode of constructing ample draperies being very close to his art. The possibility of a wider influence of Baciccio's composition would of course be conditioned by the appearance of its repetitions in engravings or drawings, none of which are known to the present author. All the same, the existence of this kind of material would not at all be surprising, especially in view of Baciccio's role of the chief "translator" of Bernini's concepts into pictorial forms. The second example is afforded by the magnificent statue of The Mother of Sorrows by Johann Meinrad Guggenbichler [Fig. 10], in a side altar of the church at Sankt Wolfgang near Salzburg, executed in $1706^{43}$. The space of half a century between the oeuvre of Guggenbichler 


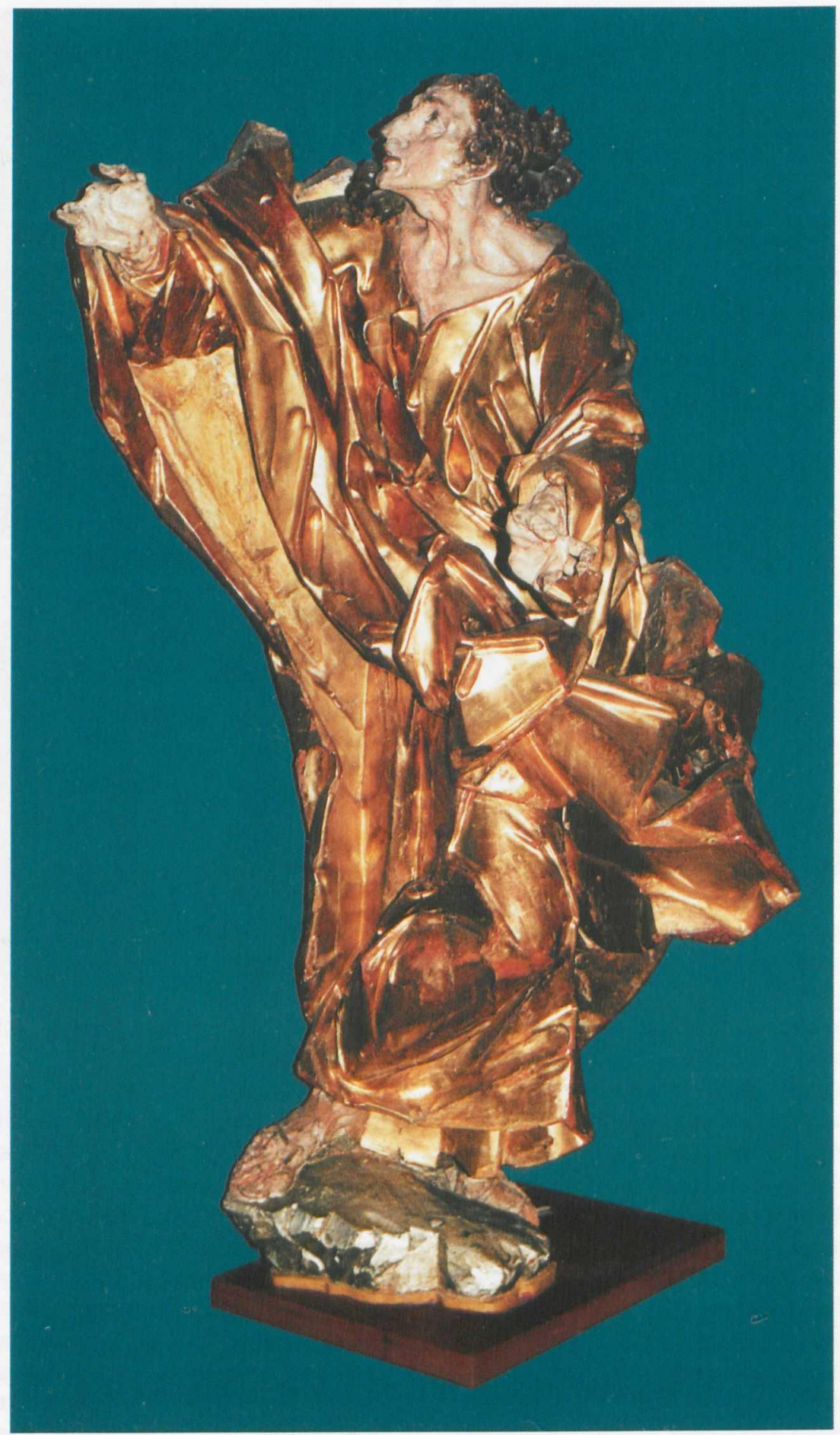

14) J. G. Pinsel, «St John the Evangelist», c. 1758, from the high altar at Hodowica. Lvov, Gallery of Art. Photo: J. K. Ostrowski. 


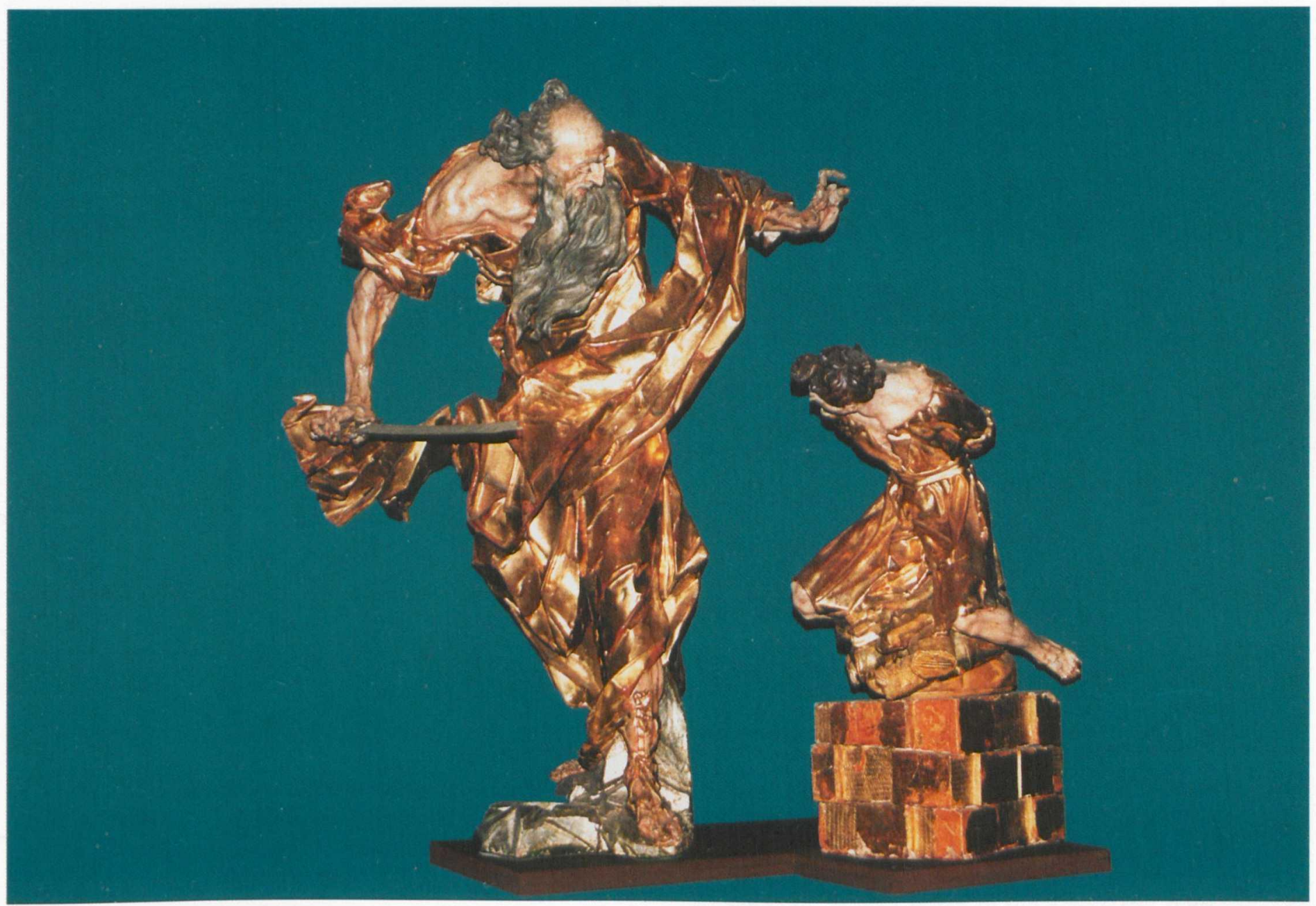

15) J. G. Pinsel, «The Sacrifice of Isaac», c. 1758, from the high altar at Hodowica. Lvov, Gallery of Art. Photo: J. K. Ostrowski.

and that of Pinsel is naturally responsible for their stylistic differences; nevertheless, in addition to evident affinities in composition, both figures belong to the same current of Central European woodcarving, reaching back to Gothic tradition. It may also be added that both Sankt Wolfgang and the neighbouring Mondsee where Guggenbichler ran a workshop, are situated on the regular route of journeyman travels from Swabia, Bavaria, and Tyrol to Vienna.

Therefore, a direct prototype for Johann Georg Pinsel's Mother of Sorrows is still waiting for identification. Should these investigations be crowned with success, the solution of some further puzzles would perhaps be possible, such as, for instance, the question of the origins of the striking resemblance between the face of The Mother of Sorrows from Hodowica and that of the Madonna from the Pietà group in the cemetery chapel at Nenningen, executed by Ignaz Günther in 1774 [Fig. 13] ${ }^{44}$. As a matter of fact, one would not be surprised to find that the model so persistently searched for never existed in a definite, individual form. After all, the abilities of an artist such as Pinsel enabled him in full to create an independent composition of this kind. At any rate the composition of the Hodowica Mother of Sorrows was an extraordinary suc- 


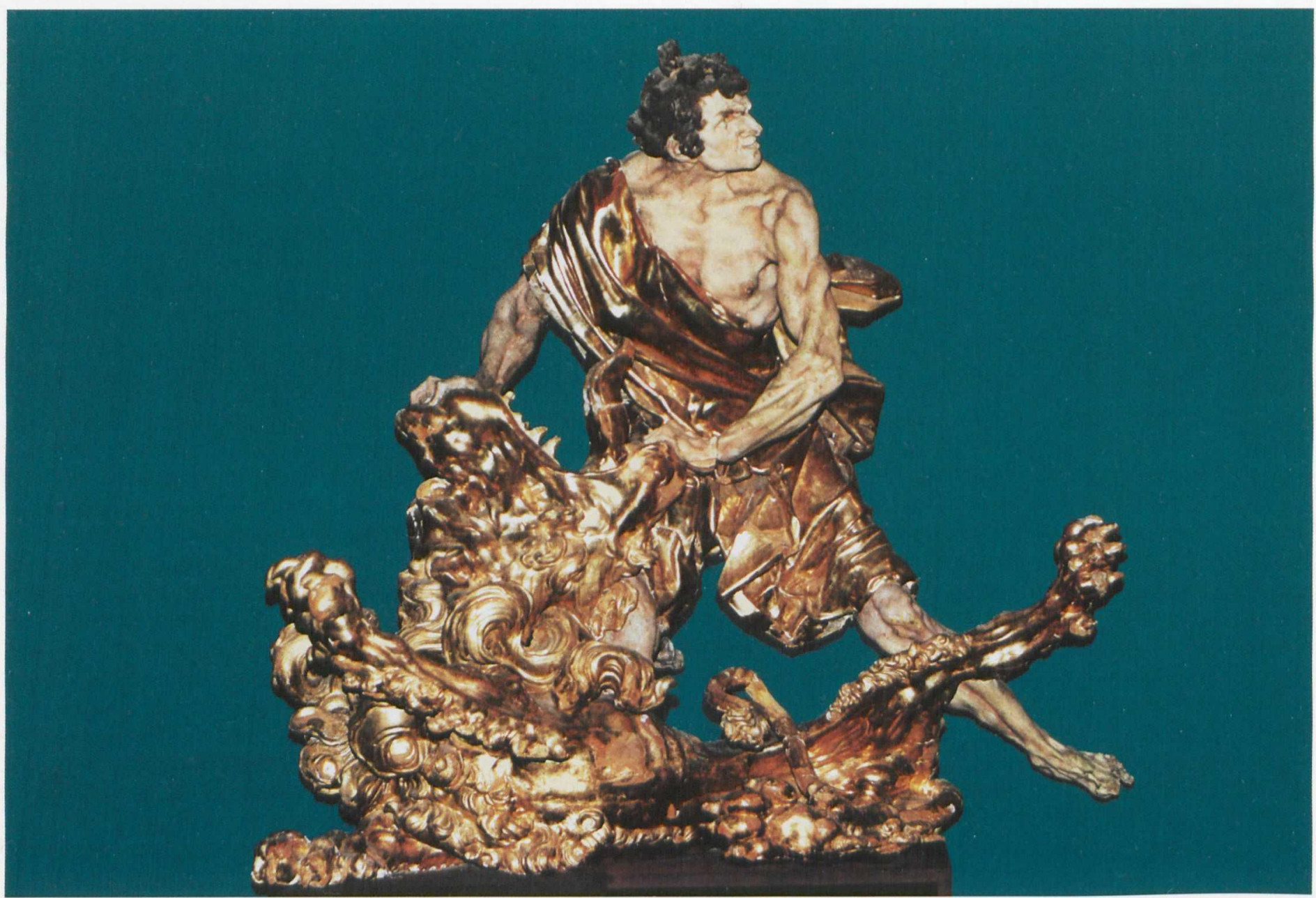

16) J. G. Pinsel, "Samson and the Lion», c. 1758, from the high altar at Hodowica. Lvov, Gallery of Art. Photo: J. K. Ostrowski.

cess in the Lvov circle. A dozen or so examples of its faithful imitations may be adduced here. Interestingly enough in some cases the motif of wiping away tears was abandoned, this permitting the application of the model to a different iconographic context ${ }^{45}$.

The statue of St John the Evangelist [Fig. 14], corresponding to that of The Mother of Sorrows, is generally somewhat inferior. In particular, the exaggerated dynamism of the contrapposto is not convincing, nor is the excessively ample, as it were, fold of the cloak hanging from the saint's right hand. Otherwise, the sculpture exhibits all characteristics of Pinsel's technical excellence, especially conspicuous in the handling of the face and hair. The composition of this sculpture was faithfully reproduced in the altars at Busk and Brzozdowce ${ }^{46}$, and it is no wonder, since those churches are integral replicas of Meretyn's structure at Hodowica 47 .

The Sacrifice of Isaac [Fig. 15] and Samson and the Lion [Fig. 16] groups are two of Pinsel's most impressive works. They were intended to be viewed from different angles. There have been attempts to see in the composition of the first of 


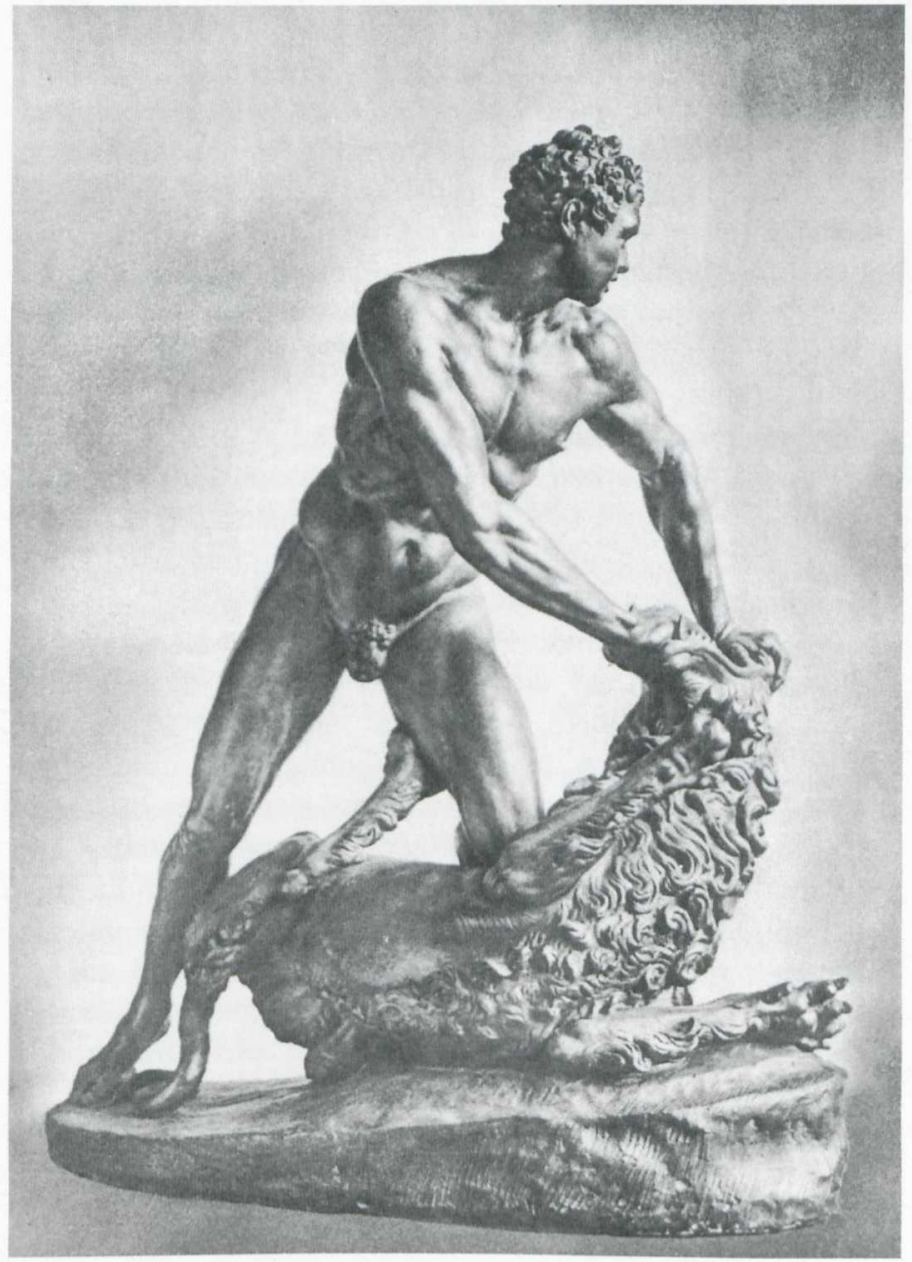

17) S. Maderno, «Hercules and the Lion», 1621, Venice, Ca' d'Oro. After A. E. Brinckmann, Barock Bozzetti, vol. 2, Frankfurt a. Main, 1924, il. 12.

them an inspiration by the Laokoon group ${ }^{48}$. The extremely dynamic figure of Abraham is rendered as an almost Mannerist figura serpentinata, and the idea of the strong leaning forward of the entire figure is perhaps derived from Bernini $^{49}$. The prophet's ascetic physiognomy, with subtly worked details of the eyes and hair, resembles the much damaged monumental sculptures of the high altar in the church at Horodenka. The small figure of Isaac (after its completion wrapped in a textile garment) is markedly inferior, probably executed by one of Pinsel's assistants.
The Samson and the Lion group, owing to its exceptional expressive and decorative merits, is the best known work by Pinsel, though it was not included in the exhibitions of his oeuvre in Prague, Warsaw, or Wroclaw. As demonstrated by detailed studies, Pinsel made use here of a scheme of composition known from antiquity, but finally codified by Stefano Maderno in his sculpture Hercules and the Nemean Lion, of 1621 [Fig. 17]. Maderno's original is a modest terracotta modello (Venice, Ca' d'Oro), but in the $18^{\text {th }}$ century its form was widely known in various Central European centres ${ }^{50}$. Evidently Pinsel highly valued Maderno's composition (though of course we do not know if he was aware of its authorship - it would not be surprising if he took it for an antique work) and at the very beginning of his activity in Poland executed from this model one of the sculptures decorating the parapet of the townhall at Buczacz. In the Hodowica version he handled the model freely, reversing directions of its composition (similarly as did František Platzer in a drawing at the Národni Galerie in Prague) and giving the sculpture all features of his individual style. The half-naked figure of Samson is composed of almost abstract knots of musculature, typical of Pinsel (as mentioned above, the figure, originally practically naked, was covered with a drapery made of plaster-stiffened fabric). The hero's physiognomy is puzzling on account of its non-classical character, suggesting its being a portrait. However, the lion has been treated in the most unusual manner. Maderno's small and not very dangerous animal was turned by Pinsel into a real beast with an enormous mouth and the body composed of well-nigh abstract forms, resembling flame-like rocaille motifs.

The altar in the Hodowica church must have made an exceptional impression on the beholder. The real and painted architecture, mobile forms of the sculptures glittering with gilding, and the light coming from visible and concealed sources combined to produce the magnificent effect of the Late Baroque theatrum sacrum. It is worth emphasizing the creation of such a complex and high-quality work of art in a village church in which, despite its being situated not far from Lvov, the sculptures could not count on sophisticated viewers. The founder of the church, Rev. Szczepan Mikulski, engaging eminent artists and together with them responsible for the concept of the church, evidently did it to the glory of God and also to satisfy his own refined aesthetic needs. It is perhaps not accidentally that he decided to choose Hodowica as his permanent residence in the last years of his life.

The architecture and decoration of the Hodowica church were very highly valued by the contemporaries, as is attested by the creation of its replicas at Kolomyja (1761-1772), Busk (after 1766-before 1779), Łopatyn (c. 1772), and Brzozdowce (c. 1769) (the first three were founded by the Rev. Mikulski). In 
at least two of them (Busk, Brzozdowce) it was also attempted to repeat the arrangement of the Hodowica high altar. Undoubtedly copies of the design of Meretyn and Pinsel were used by builders on the sites, but none of the imitations realised after the death of both masters attained the quality of the original ${ }^{51}$.

Likewise, Johann Georg Pinsel had an immense impact on the development of sculpture in the Lvov circle between about 1760 and 1780 . Most of his figures served as models imitated several or even some dozen times ${ }^{52}$. His drawings, bozzetti and modelli, must have counted among the most valued technical aids. It is interesting to note that there were frequent attempts to reduce his sculptures to relief forms. For all the extraordinary popularity of the master's prototypes, only the most talented of his imitators were able to refer relatively integrally to his work, but they remained far behind the expressive power of his creations.

Johann Georg Pinsel's oeuvre requires further study. First of all the place of his artistic training remains to be established. The present state of research proves that he was an excellent representative of Central European technical tradition, which he harmoniously combined with Italian inspirations. Attempts to associate him with the Prague milieu ${ }^{53}$, not at all groundless, on account of the character of his expressionism, akin to that appearing in Matias Bernard Braun and Ignac Rohrbach (active in Chrudim), need to be developed and ascertained by source material. It is also worth asking a "demodé" question about the stylistic determination of Pinsel's art. For Central European sculpture (especially Bavarian, but also Lvov) the term "Rococo" has been adopted, which is justified by the specific character of development of art in these territories. However, for the sake of terminological precision, Pinsel would have to be ranked as a Late Baroque rather than Rococo master, owing to the dynamism, expression, and religious pathos of his art. A truly Rococo delicacy and grace distinguish the works of the younger generation of Lvov sculptors, with Maciej Polejowski at the head of them, who were active from the 1760 s to 1780 s.

The here-presented fragment of Johann Georg Pinsel's oeuvre and Bernard Meretyn's work constituting its architectural setting, are but a fraction of $18^{\text {th }}$ century artistic output in the former eastern territories of the Polish Commonwealth, today in Lithuania, Byelorussia, and Ukraine. The sculpture of the Lvov circle, with Pinsel as its most outstanding representative, is its most valuable manifestation among the visual arts. Its direct counterpart in architecture were the works of Bernard Meretyn but also those of Jan de Witte who worked contemporarily on the same territory, and the entire Wilno (Vilnius) school of architecture with its chief exponent Johann Christoph Glaubitz. This art, dramatically decimated owing to historical circumstances and not yet thoroughly investigated, proves that the culture of Central Europe reaches much farther to the east and north than is usually accepted. 
1 W. Żyła, Kościót i klasztor Dominikanów we Lwowie, Lwów 1923 , p. 72.

2 P. Krasny, J. K. Ostrowski, "Wiadomości biograficzne na temat Jana Jerzego Pinsla", Biuletyn Historii Sztuki LVII, 1995, pp. 339-342; all available data about the artist's biography against a comparative background are to be found in J. K. Ostrowski, "Jan Jerzy Pinsel, zamiast biografii", [in:] Sztuka kresów wschodnich, vol. 2, ed. J. K. Ostrowski, Kraków 1996, pp. 361-373.

3 See especially: T. Mańkowski, Lwowska rzeźba rokokowa, Lwów 1937; Z. Hornung, Antoni Osiński, najwybitniejszy rzeźbiarz Iwowski XVIII stulecia, Lwów 1937; Z. Hornung, Majster Pinsel snycerz, Wrocław 1976; B. Woźnicki, Mistrz Pinsel. Legenda i rzeczywistość [exhibition catalogue], Wilanów 1990; J. K. Ostrowski, "W kręgu mistrza Pinsla. W związku z wystawą w Olesku i we Lwowie", Folia Historiae Artium 26, 1990, pp. 149-165; J. K. Ostrowski, "Z problematyki warsztatowej i atrybucyjnej rzeźby Iwowskiej w. XVIII", [in:] Sztuka kresów wschodnich, vol. 1, ed. J. K. Ostrowski, Kraków 1994, pp. 79-104; J. K. Ostrowski, "Hercules and Samson. A Long Way of a Composition Motif from Stefano Maderno to Johann Georg Pinsel", [in:] Gedenkschrift für Richard Harprath, ed. W. Liebenwein i A. Tempestini, München-Berlin 1998, pp. 311-322.

4 Ostrowski, “Jan Jerzy Pinsel, zamiast biografii...”, p. 364.

5 The marriage certificate of Johann Georg Pinsel and Marianna Majewska, widow of Jan Kieyt (13 V 1751) is the earliest known document relating to the artist; see Krasny, Ostrowski, op. cit., pp. 340-341.

6 Mańkowski, op. cit., pp. 159-160.

7 Krasny, Ostrowski, op. cit., pp. 340-341.

8 Ostrowski, "Jan Jerzy Pinsel, zamiast biografii...", p. 364 (when he was getting married in 1751, the artist was a bachelor and not widower, and to be married was one of the conditions of becoming a guild master).

9 Materialy do dziejów sztuki sakralnej na ziemiach wschodnich dawnej Rzeczypospolitej, ed. J. K. Ostrowski, part I, vols. 1-7, Kraków 1993-1999.

10 T. Mańkowski, Lwowskie kościoły barokowe, Lwów 1932, p. 92.

11 В. Любченко, "Нові твори львівських скульпторів XVI-XVIII ст. у галереї (На матеріалах збирацької роботи 1965 року)" [in:] Львівська Картйнна Галерея. Виставки, знахідки, дослідження, Львів 1967, pp. 23-24; Gębarowicz, "Prolegomena do dziejów Iwowskiej rzeźby rokokowej”, Artium Questiones 3, 1986, pp. 14-15, ill. 10; Materiały do dziejów sztuki sakralnej..., part I, vol. 1, 1993, p. 34, ill. 125.

12 Mańkowski, Lwowska rzeźba rokokowa..., pp. 35-36, 91-93.

13 Hornung, Antoni Osiński..., pp. 31-33; Hornung, Majster Pinsel..., pp. 43-45.

14 Mańkowski, Lwowska rzeźba rokokowa..., p. 35.

15 Hornung, Antoni Osiński..., p. 33.

16 K. Brzezina, "Materialy do dziejów artystycznych kościola Trynitarzy p.w. Trójcy Przenajświętszej we Lwowie", [in:] Sztuka kresów wschodnich, vol. 2, Kraków 1996, pp. 196, 201.

17 J.E. Dutkiewicz, "Fabryka cerkwi Wniebowzięcia NMP w Poczajowie", Dawna Sztuka 2, 1939, p. 144; J. Kowalczyk, "Ze studiów nad geografią Iwowskiej rzeźby rokokowej", [in:] Rokoko. Materiaty sesji SHS, Warszawa 1970, p. 201.

18 Ostrowski, "Z problematyki warsztatowej...", p. 85. Thus far it has been impossible to associate the works attributed to that close collaborator and follower of Pinsel with any concrete person, who was probably one of quite a numerous group of Lvov sculptors appearing in written sources, but to whom not a single work can be attributed.
19 Krasny, "Kościół parafialny w Hodowicy...", pp. 42-43.

20 Krasny, "Kościół parafialny w Hodowicy...", pp. 44-45; for the organization of Meretyn's workshop and his great care of all details concerning the execution of his buildings see P. Krasny, Bernard Meretyn i problem rokoka w architekturze polskiej, Kraków 1994 (dissertation), pp. 33-43.

21 E. Rastawiecki, Słownik malarzów polskich tudzież obcych w Polsce osiadlych lub czasowo w niej przebywających, Warszawa 1850-1857, vol. 3, p. 378.

22 This opinion was held by Mańkowski, Lwowska rzeźba rokokowa..., p. 139, M. Gębarowicz, op. cit., pp. 26-27; Krasny, "Kościół parafialny w Hodowicy...", p. 39. Z. Hornung (Stanisław Stroiński 1719-1802. Zarys monograficzny ze szczególnym uwzględnieniem działalności artysty na polu malarstwa ściennego, Lwów 1935, p. 49 and Majster Pinsel snycerz..., p. 44), considered the Hodowica altar a temporary solution, as he believed Meretyn's death to have prevented the execution of an architectonic retable.

23 The etching was published in G. Galli Bibiena, Architetture e prospettive, Augsburg 1740, no. 5; I wish to thank Dariusz Kucia, MA for indicating of this source of composition.

24 Krasny, "Kościół parafialny w Hodowicy...", p. 47, ill. 10.

25 Krasny, "Kościół parafialny w Hodowicy...", p. 46.

26 The characteristics of the iconographic programme, mainly after Krasny, "Kościół parafialny w Hodowicy...", pp. 48-49.

27 On Sierakowski's activity see especially J. Ataman, W. H. Sierakowski $i$ jego rządy $w$ diecezji przemyskiej, Warszawa 1936. The intellectual and theological aspects of the Catholic Enlightenment in Poland are presented by J. Kracik, "Ewangelicznie i rozumnie. Oświecenie katolickie", Znak 44, 1992, no. 451, pp. 57-69.

28 Sculptured figural and ornamental elements are clearly seen on the only surviving design by Meretyn-a longitudinal section of St George's Cathedral in Lvov, see Mańkowski, Lwowskie kościoły barokowe..., pp. 112, ill. 53.

29 See note 11 . In connection with the discovery of the signature some Ukrainian scholars tried to attribute to Meretyn the execution of the relief sculpture, see Любченко, op. cit., pp. 23-24; Д. П. Крвавич, "Лвівська бароккова скульптура: Джерела інспірацій", [in:] Українське барокко та эвропейський контекст, Київ 1991, pp. 97-98.

30 Close contacts between the two artists are attested by the fact that Meretyn was the godfather of Pinsel's son Bernard, born 1752; see Krasny, Ostrowski, op. cit., pp. 340-341.

31 Gębarowicz, op. cit., p. 15. Similar practices were known in Rome, see J. Montagu, Roman Baroque Sculpture. The Industry of Art, New Haven-London 1989, p. 113. Identically prepared textile draperies can also be found in some works by Ignaz Günther.

32 An almost total ignorance of the principles of perspective is visible in numerous relief sculptures created in the circle of Lvov school.

33 Ostrowski, "From Maderno to Pinsel..."; P. Krasny, Hodowicka figura Matki Boskiej Bolesnej. Uwagi o genezie schematu kompozycyjnego (in press).

34 See e.g. P. Volk, Ignaz Günther. Vollendug des Rokoko, Regensburg 1991, pp. 146-147.

35 This sculpture, the sole example of Pinsel's art accessible on the present territory of Poland, has recently been shown in great exhibitions in Germany and the USA, see Kunst und Kultur der sächsischpolnischen Union, [exhibition catalogue] Leipzig 1997, p. 106; Land of the Winged Horsemen. Art in Poland 1572-1764, [exhibition catalogue] Alexandria, Va., 1999, pp. 242-243.

36 On the popularity of this motif see e.g. O. J. Blažiček, "Ikonografie česke barokové plastiky", Pamatki Archeologické, 19-16 (42), 1939-1946, p. 78. 
37 Ostrowski, "Z problematyki warsztatowej...", p. 85.

38 Ostrowski, "Z problematyki warsztatowej...", p. 82. Reproductions of sculptures-see in Materiały..., part. I, vol. 1, 1993, ill. 226, 227.

39 On this concept see especially: R. Wittkower, Gian Lorenzo Bernini-the Sculptor of the Roman Baroque, London 1966; R. Preimesberger, "Themes from Art Theory in the Early Works of Bernini", [in:] Gianlorenzo Bernini: New Aspects of his Art and Thought, ed. I. Lavin, University Park-London 1985, pp. 1-18; G. Careri, Bernini: Flights of Love, the Art of Devotion, Chicago-London 1995.

40 Krasny, Hodowicka figura Matki Boskiej Bolesnej....; attribution and dating after M. Stehlík, "Nuovi particolari sull'opera di Giov, Giuliani”, Sbornik Praci Filosofské Fakulty Brněnské University, Series F, 14-15, 1981, pp. 275-276; I. Rusina, "L'oeuvre de Giuliani au Chemin de Croix de Bratislava", Ars, 1975/1976, nr 1-4, pp. 113-117.

41 Krasny, Hodowicka figura Matki Boskiej Bolesnej...

42 See R. Enggass, The Paintings of Baciccio Giovanni Battista Gaulli 1639-1709, University Park 1964, pp. 5-6, 155, ill. 3.

43 H. Decker, Meinrad Guggenbichler, Wien 1949, pp. 55, 86, no. $65 c$, ill. 59,60 , pl. 3
44 See e.g. Volk, Ignaz Günther..., pp. 244-247.

45 Ostrowski, "W kręgu mistrza Pinsla...", pp. 158-160; Ostrowski, “Z problematyki warsztatowej...”, p. 80.

46 Ostrowski, “Z problematyki warsztatowej...”, p. 81.

47 Mańkowski, Lwowskie kościoły barokowe..., pp. 92-93; P. Krasny, "O problemach atrybucji architektury nowożytnej. Kościoly w Kołomyi, Busku, Brzozdowcach i Łopatynie a twórczość Bernarda Meretyna", Folia Historiae Artium, 30, 1994, pp. 119-129.

48 Gębarowicz, op. cit., pp. 15-16; Woźnicki, Mistrz Pinsel..., p. 25.

49 A copy of Bernini's drawing with the similarly rendered figure of Cain is reproduced in J. Białostocki, Dwugłos o Berninim (Baldinucci i Chantelou), Wrocław 1962, ill. 36.

50 Ostrowski, "Hercules and Samson...".

51 Mańkowski, Lwowskie kościoły barokowe..., pp. 92-93; Krasny, "O problemach atrybucji...".

52 Ostrowski, "W kręgu mistrza Pinsla...”, pp. 158-164; Ostrowski, "Z problematyki warsztatowej...", pp. 80-81.

53 See especially Hornung, Majster Pinsel snycerz..., pp. $152-$ 157. 